\title{
IMPLEMENTASI APLIKASI BERBASIS ANDROID PENGEMBANGAN IDE RESEP MAKANAN DAN MINUMAN PADA RESTORAN
}

\author{
Sitti Aisa, ST. Aminah Dinayati Ghani \\ Program Studi Teknik Informatika, Universitas Dipa Makasar \\ J1. Perintis Kemerdekaan KM.9 Makassar, Sulawesi Selatan \\ sitti.aisa@dipanegara.ac.id, dinayati.amy@dipanegara.ac.id
}

\begin{abstract}
This study aims to design and implement an android-based application for the development of food and beverage recipe ideas. Data collection techniques in this study are observation and interviews. The test model that will be carried out in this study is Black Box testing. System modeling using Unifield Modeling Language (UML) The results of testing an android-based application for the development of cooking and beverage ideas in restaurants and tests carried out using this application restaurant owners can develop recipes where they receive recipe ideas from visitors and can easily see the sales that occur in restaurants and can assist chefs in implementing recipes given by visitors so as to increase the number of food menus in the restaurant.
\end{abstract}

Keywords - Android, Applications, Food, Beverages, Restaurants

Abstrak - Penelitian ini bertujuan untuk merancang dan mengimplementasikan aplikasi berbasis android pengembangan ide Resep makanan dan minuman. Teknik pengumpulan data dalam penelitian ini yaitu observasi dan wawancara. Model pengujian yang akan dilakukan dalam penelitian ini adalah pengujian Black Box. Pemodelan sistem dangan Unifield Modeling Language (UML) Hasil pengujian implementasi aplikasi berbasis android untuk pengembangan ide masakan dan minuman pada restoran serta pengujian yang dilakukan penggunaan aplikasi ini pemilik restoran dapat mengembangkan resep masakan dimana menerima ide resep masakan dari pengunjung dan dapat dengan mudah melihat penjualan yang terjadi di restoran serta dapat membantu koki dalam mengimplemetasi resep yang telah diberikan oleh pengunjung sehingga menambah jumlah menu makanan yang ada direstoran.

Kata Kunci - Android, Aplikasi, Makanan, Minuman, Restoran

\section{PENDAHULUAN}

Secara harfiah, bisnis dapat diartikan sebagai aktivitas menghasilkan uang dan mencari nafkah. Memiliki bisnis sendiri adalah dambaan kebanyakan orang, jika bisnis Anda dalam keadaan baik dan bisa memberikan penghasilan tetap setiap bulannya, itu adalah kepuasan tersendiri. Melihat semakin banyaknya orang yang suka mencari berbagai menu makanan, baik makanan tradisional, domestik maupun internasional, permintaan industri memasak Indonesia semakin meningkat. Itu bisa dibuktikan dari Persaingan dari waktu ke waktu untuk mendapatkan minat konsumen, dan tentunya menu Chinese food masing-masing.[1]

Saat ini banyak terdapat restoran, resto dan cafe dengan konsep menu makan yang unik dan menarik. Para pengusaha bisnis kuliner berlomba-lomba mengembangkan ide bisnis kulinernya. Menciptakan kepuasan konsumen juga menjadi tujuan terpenting para pengusaha kuliner. Konsumen yang merasa puas akan membawa calon konsumen baru menjadi pengusaha kuliner. Mereka akan menceritakan pengalaman menu dan layanan mereka di sini.
Menjaga kepuasan pelanggan dan meningkatkan kepuasan memang tidak mudah. Untuk itu, diperlukan orang-orang kreatif di dalam dan di luar restoran untuk mengembangkan menu para pengusaha kuliner.

Saat ini kami belum menemui kendala dalam memberikan kesempatan kepada konsumen restoran untuk memberikan konsep menu makan yang unik dan menarik kepada pemilik restoran. Dengan pesatnya perkembangan teknologi, saat ini dimungkinkan untuk memiliki aplikasi yang dapat memenuhi kebutuhan setiap pengguna smartphone, terutama aplikasi yang berperan sebagai perantara pemilik dan pengunjung restoran untuk menyampaikan ide-ide unik dan menarik. . Diharapkan dengan pesatnya teknologi yang terus berjalan akan membantu memberikan pelayanan yang memuaskan kepada customer serta memberi memudahkan dalam pengiriman pesanan makanan dan minuman ke restoran.

Penelitian yang berjudul "Rancang Bangun Aplikasi Pemesanan Makanan Online Pada Restoran Cepat Saji Berbasis Mobile Application " [2] dengan objek penelitiannya Chicken Mania Cabang Rungkut, dimana pada penelitian ini menghasilkan penerapan 
aplikasi berbasis mobile yang dapat memudahkan pelanggan dalam melakukan order makanan secara online dan memperkecil penggunaan pulsa telepon serta aplikasi berbasis web yang dapat memudahkan pihak restoran memantau pesanan pelanggan serta dapat memelihara data - data yang berkaitan dengan pemesanan online. Penelitian yang berjudul "Aplikasi Pemesanan Makanan Berbasis Android Di Restoran 4 Sekawan "[3], dari penelitian ini memberikan hasil penerapan aplikasi untuk memudahkan customer untuk melakukan pemesanan makanan melalui handphone, serta pelanggan dapat menjadi member yang dapat melakukan transaksi tanpa harus mendatangi restoran.

Penelitian yang berjudul "Rancang Bangun Aplikasi Pemesanan Makanan Berbasis Android pada rumah makan bengawan tepi sawah" [4], dimana hasil penelitiannya berupa aplikasi pemesanan yang dibangun menggunakan bahasa php dan java. Pada penerapan aplikasinya sendiri terdapat dua bagian yaitu pelanggan dan admin. Pada sisi pelanggan atau user aplikasi, pelanggan dapat melakukan pemesanan menu yang dibutuhkan. Sedangkan pada sisi admin, pengelola admin dapat menerima informasi pesanan masuk yang dilakukan oleh pelanggan, dan dapat mengelola perubahan dan pembaruan terhadap aplikasi seperti kelola transaksi, kelola menu, kelola meja, kelola reservasi. Penelitian yang berjudul "Rancang Bangun Aplikasi Pemesanan Menu Makanan Restoran Berbasis Android"'[5], dimana hasil penelitian ini berupa aplikasi pemesanan menu restoran berbasis android ini dikembangkan menggunakan teknologi web dengan memanfaatkan framework cordova sebagai cross-platform dan framework ionic. Kedua framework tersebut dapat membangun aplikasi ini dengan baik dan cepat.

Penelitian ini bertujuan untuk merancang dan mengimplementasikan aplikasi berbasis android untuk pengembangan ide masakan dan minuman pada restoran, pemilik dapat dengan mudah melihat penjualan yang terjadi di restoran serta dapat membantu koki dalam mengimplemetasi resep yang telah diberikan oleh pengunjung,

\section{A. Restoran}

Berdasarkan tujuannya Restoran dibagi menjadi dua pengertian yang dibagi menjadi Onsite foodservice yang secara operasional menjual makanan hanya untuk mendukung aktifitas utama dan biasanya tergolong non-profit, sedangkan commercial foodservice secara operasional menjual makanan adalah prioritas utama dan keuntungan diinginkan.[6]

\section{B. Resep Makanan}

Resep masakan adalah deskripsi, yang berisi nama hidangan, bahan, bumbu, cara penyiapan, dan hidangan. Resep adalah sekumpulan instruksi atau algoritma yang menunjukkan cara membuat hidangan.
Pengetahuan yang dibutuhkan untuk membuat resep masakan sebagai berikut [7]:

1. Pengetahuan bahan makanan.

2. Pengetahuan alat masak dan alat hidang.

3. Pengetahuan tentang teknik olah.

4. Pengetahuan tentang tata hidang serta pengetahuan tentang ukuran.

\section{Aplikasi}

Aplikasi adalah program yang berisikan isntruksi-instruksi dalam mengolah data. Secara umum aplikasi dapat diartikan suatu proses mengubah cara manual ke komputer dengan membuat sistem atau program untuk dapat data diolah lebih berdaya guna secara optimal.[8]

\section{Android}

Definisi sistem operasi berbasis Android Linux yang dirancang untuk perangkat seluler layar sentuh (seperti smartphone dan tablet) ". Android pada awalnya dikembangkan oleh Android, Inc. dengan dukungan finansial dari Google, dan kemudian diakuisisi oleh Google pada tahun 2005. Sistem operasi tersebut Ini resmi dirilis pada tahun 2007. Antarmuka pengguna Android didasarkan pada manipulasi langsung, menggunakan input sentuh yang mirip dengan tindakan dunia nyata, seperti menggeser, mengetuk, mencubit, dan membalik mencubit untuk memanipulasi objek di layar.

Android adalah sistem operasi open source, dan Google merilis kodenya di bawah lisensi Apache. Kode sumber terbuka dan lisensi berlisensi di Android memungkinkan produsen perangkat, operator nirkabel, dan pengembang aplikasi untuk dengan bebas memodifikasi dan mendistribusikan perangkat lunak.[9].

\section{E. Makanan}

Makanan biasanya berasal dari tumbuhan dan hewan, dan organisme memakannya untuk mendapatkan nutrisi dan energi. Umumnya bahan makanan mengandung beberapa unsur atau senyawa, seperti air, karbohidrat, protein, lemak, vitamin, enzim, pigmen, dan sebagainya.[10]

\section{F. Unifield Modelling Language ( UML)}

Unifield Modeling Language (UML) merupakan bahasa standar yang banyak digunakan di industri untuk menentukan kebutuhan, melakukan analisis dan desain, serta mendeskripsikan arsitektur dalam pemrograman. $U M L$ terdiri dari beberapa diagram yang umum digunakan yaitu use case diagram, class diagram, activity diagram dan sequence diagram [11] 


\section{METODE PENELITIAN}

A. Tahap Penelitian

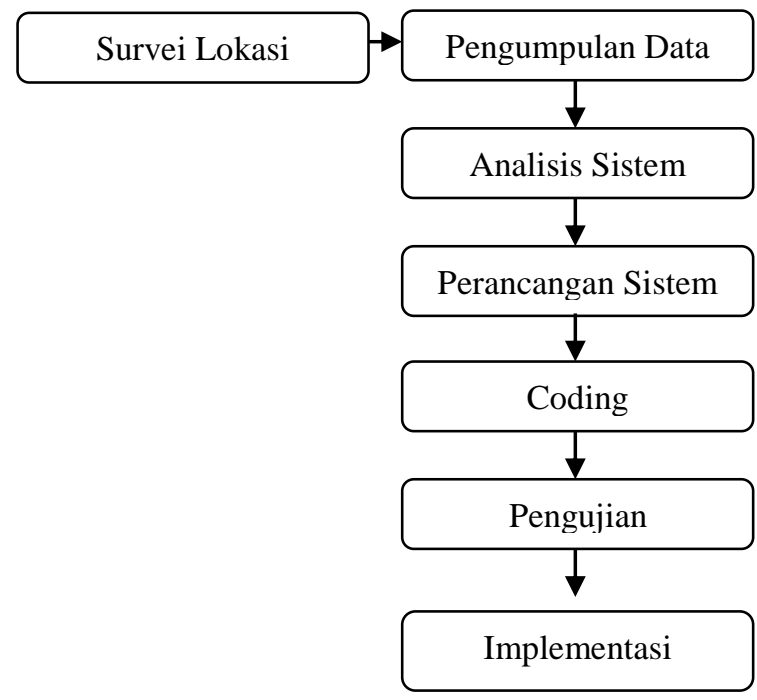

Gambar 1. Tahapan penelitian

Tahap-tahap yang dilakukan dalam membangun aplikasi ini adalah sebagai berikut:

1. Survei lokasi : melihat tempat penelitian.

2. Pengumpulan data : mengumpulkan informasi yang dilakukan secara langsung ke tempat penelitian.

3. Analisis Sistem : Menguraikan aplikasi yang lengkap menjadi komponen-komponennya untuk mengidentifikasi dan mengevaluasi masalah, peluang, hambatan, dan kebutuhan yang diantisipasi, sehingga dapat menyarankan perbaikan.

4. Perancangan sistem : merupakan strategi untuk memecahkan masalah dan mengembangkan solusi terbaik bagi permasalahan.

5. Coding : bahasa pemrograman yang menerjemahkan persyaratan logika dari kode semu atau diagram alir ke dalam huruf, angka, dan simbol yang membentuk program.

6. Pengujian Aplikasi : Ketahui cara mendesain aplikasi secara detail sesuai spesifikasi, dan evaluasi apakah setiap fungsi atau proses desain tidak memiliki kesalahan logika.

7. Implementasi : Program aplikasi dibuat berdasarkan hasil perancangan sistem yang ada untuk mencapai tujuan yang diinginkan. Menerapkan perintah dengan cara terstruktur dari awal hingga akhir.

\section{B. Perancangan Sistem}

\section{Use Case diagram}

Use case diagram berfungsi untuk menjalankan sistem jika dilihat menurut pandangan orang yang berada di luar sistem (actor). Pada sistem ada beberapa actor yang terlibat dimana actor tersebut yang menggunakan sistem pengembangan resep makanan dan minuman pada restoran.

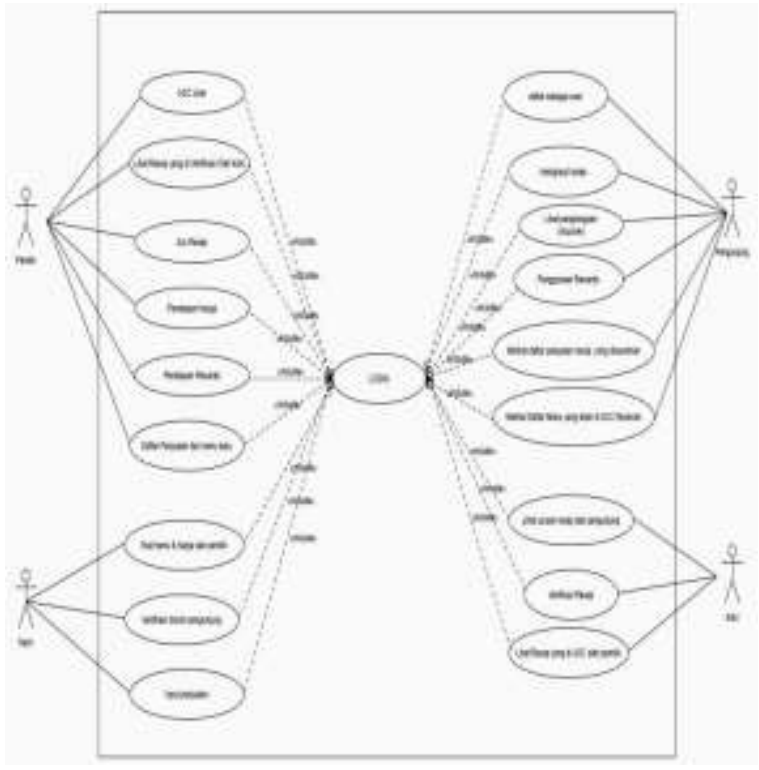

Gambar 2. Perancangan Use Case Diagram

Dari gambar 2 telah tergambarkan sebuah use case diagram didalamnya terdapat empat actor yaitu Pengunjung, Pemilik, Koki dan Kasir. User Pengunjung memiliki lima proses/fungsi yang dapat dilakukan yaitu mendaftar sebagai user, menyarankan resep, melihat penghargaan (voucher) dan meihat daftar resep yang ada. Pada user Pemilik terdapat enam proses/fungsi yang dapat dilakukan yaitu Acc pendaftaran user, melihat resep yang di sarankan, Acc saran resep yang masuk, penentuan harga resep baru, pemberian penghargaan dan melihat daftar penjualan resep baru. Pada user Koki ada tiga proses/fungsi yang dapat dilakukan yaitu melihat saran resep, verifikasi resep dan melihat resep yang di Acc oleh Pemilik. Pada user Kasir terdapat tiga proses/fungsi yaitu melihat resep baru, menukarkan voucher, mendaftar penjualan dari resep.

\section{Activity Diagram}

Activity diagram berfungsi untuk mendeskripsikan rangkaian sebuah aliran dari aktifitas. Activity diagram juga digunakan untuk mendeskripsikan aktivitas yang terbentuk dalam operasi sehingga dapat juga digunakan untuk aktivitas lain, seperti use case diagram atau interaksi. 


\subsection{Activity Diagram login User}

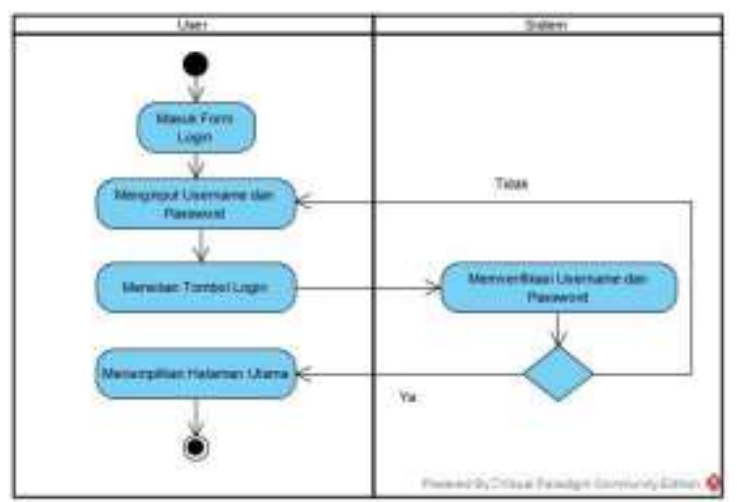

Gambar 3 Activity Diagram Login User

Pada ilustrasi gambar 3 diatas yaitu activity diagram untuk login user. Untuk mengakses sistem users terlebih dahulu harus melaui proses login, dimana pada login sistem ini terdapat empat tingkat akses yang berbeda.

\subsection{Activity Diagram Input Resep}

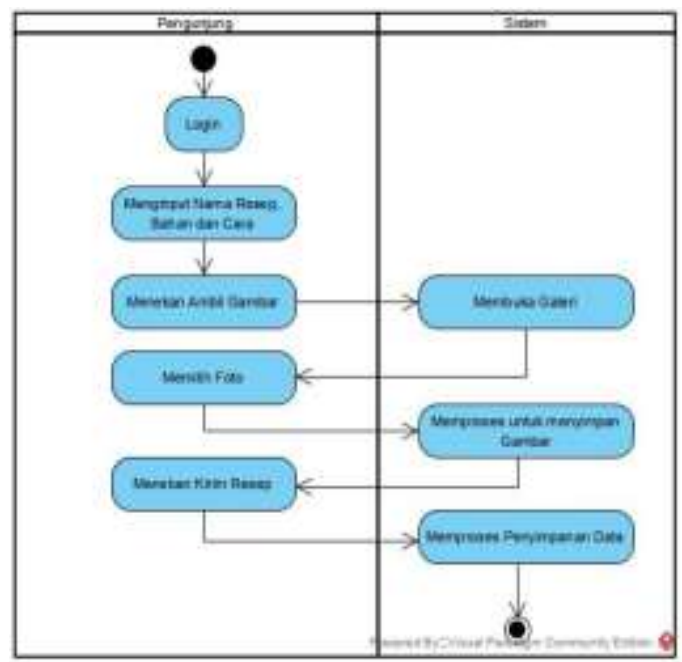

Gambar 4. Activity Diagram Input Resep

Pada ilustrasi gambar 4 diatas terdapat activity diagram untuk input resep. Pada menu Input Resep, pengunjung dapat melakukan proses penyaranan resep kepada pemilik.

\subsection{Activity Diagram Acc resep dari Admin}

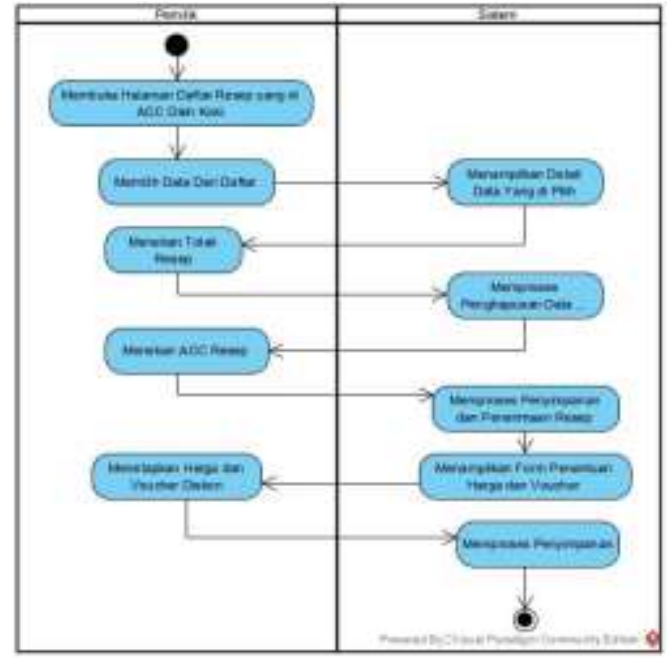

Gambar 5 Activity Diagram Acc Resep oleh Admin

Pada menu ACC Resep, admin dapat melakukan proses penolakan dan menerima resep yang di ACC oleh koki.

\subsection{Activity Diagram Klaim Voucher}

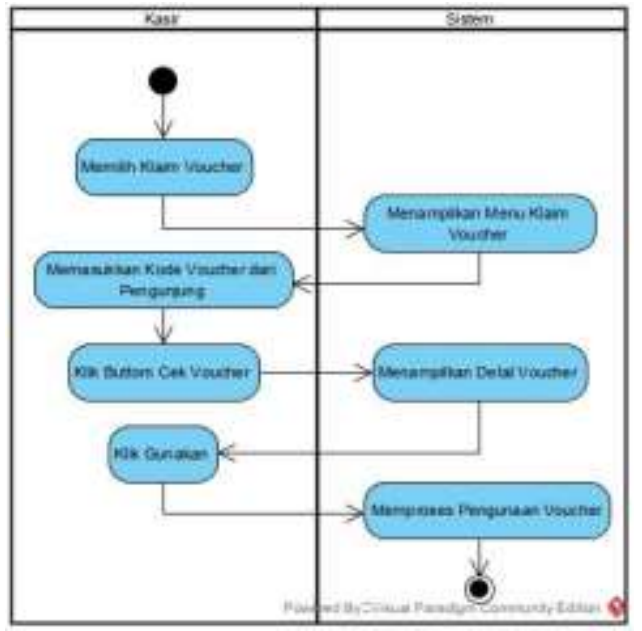

Gambar 6 Activity Diagram Klaim Voucher

Pada gambar 6 untuk activity diagram klaim voucher ada menu Klaim Voucher, kasir dapat melakukan proses verifikasi voucher yang akan digunakan oleh pengunjung.

3. Sequence Diagram

Sequence diagram adalah suatu diagram yang memperlihatkan atau menampilkan interaksiinteraksi antar objek di dalam sistem yang disusun pada sebuah urutan atau rangkaian waktu. Interaksi antar objek tersebut termasuk pengguna, display, dan sebagainya berupa mengcreate data dan sebagainya 


\subsection{Sequence Diagram Pengunjung}

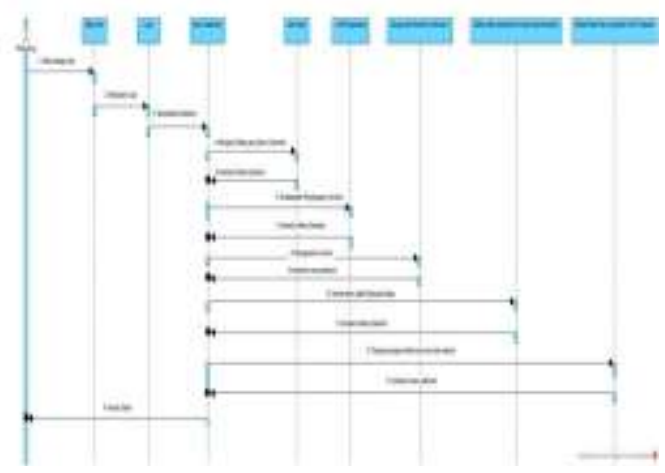

Gambar 7 Sequence Diagram Pengunjung

Pada gambar 7 Sequence Diagram Pengunjung di atas menjelaskan bahwa pengunjung terlebih dahulu menjalankan aplikasi dan menampilkan halaman Login untuk melakukan login. Namun pengunjung mendaftar terlebih dahulu agar memiliki username dan password untuk login. Kemudian username dan password akan dicek oleh sistem dan divalidasi ke menu dashboard. Selanjutnya pengunjung menyarankan resep dan mendapatkan voucher jika resep di terimah.

\subsection{Sequence Diagram Koki}

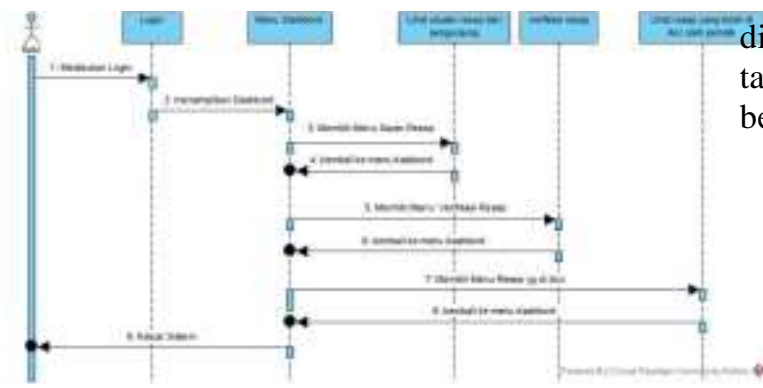

Gambar 8 Sequence Diagram Koki

Pada gambar 8 Sequence Diagram Koki di atas menjelaskan bahwa koki terlebih dahulu menjalankan aplikasi yang mana akan mengarahkan koki ke halaman Login untuk melakukan login. Kemudian username dan password akan dicek oleh sistem dan divalidasi ke menu dashboard. Selanjutnya koki akan diberikan hak untuk verifikasi saran resep. Koki selanjutnya melihat resep yang di ACC oleh pemilik.

\section{Class Diagram}

Class adalah sebuah spesifikasi yang jika diinstansiasi akan menghasilkan sebuah objek dan merupakan inti dari pengembangan dan desain berorientasi objek. Class menggambarkan keadaan (atribut atau properti) suatu sistem, sekaligus menawarkan layanan untuk memanipulasi keadaan tersebut (metoda atau fungsi). Class diagram menggambarkan struktur dan deskripsi class, package dan objek beserta hubungan satu sama lain seperti containment, pewarisan, asosiasi, dan lain-lain. Berikut kami akan menggambarkan kelas diagram sebagai berikut:

\begin{tabular}{|c|c|}
\hline data_resepp & foto_date_resen \\
\hline $\begin{array}{l}\text { tid } \\
\text { tid_user } \\
\text { tnama_fesep }\end{array}$ & $\begin{array}{l}\text { tid } \\
\text { Hode photo } \\
\text { tphoto }\end{array}$ \\
\hline $\begin{array}{l}\text { +bahan } \\
\text { tcara } \\
\text { +tgl_karm }\end{array}$ & \multirow[t]{2}{*}{$\begin{array}{l}\text { +tambah0 } \\
\text { tedito }\end{array}$} \\
\hline $\begin{array}{l}\text { thode_voucher } \\
\text { therjual }\end{array}$ & \\
\hline $\begin{array}{l}\begin{array}{l}\text { +tambaho } \\
\text { tedito }\end{array} \\
\text { foto_users }\end{array}$ & \multirow{2}{*}{ 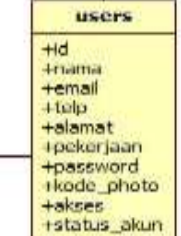 } \\
\hline $\begin{array}{l}\text { tid } \\
\text { thode_photo } \\
\text { tphoto }\end{array}$ & \\
\hline $\begin{array}{l}\text { tambaho } \\
\text { tedito }\end{array}$ & $\begin{array}{l}\text { +tambaho } \\
\text { thapuso } \\
\text { tedit0 }\end{array}$ \\
\hline
\end{tabular}

Gambar 9 Class Diagram

\section{HASIL DAN PEMBAHASAN}

A. Implementasi Aplikasi

Aplikasi pengembangan ide resep masakan ini dibuat dalam bentuk aplikasi berbasis android, dimana tampilan dari setiap jendela yang disajikan sebagai berikut :

1. Tampilan Login untuk Pengunjung ( user )

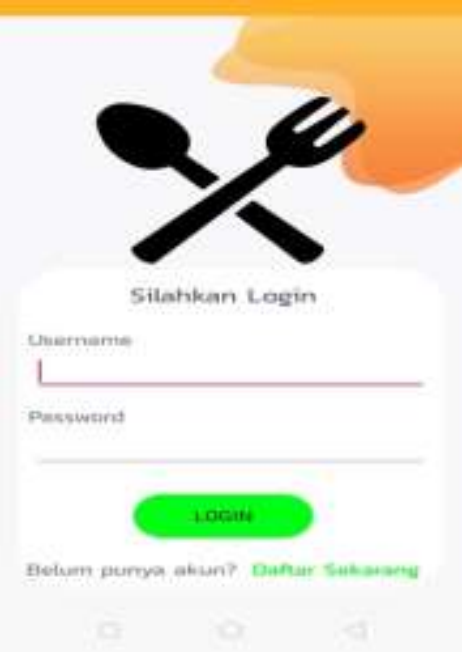

Gambar 10. Tampilan login untuk pengunjung ( user )

Pada gambar 10 ditampilkan jendela login bagi pengunjung. 
2. Tampilan Daftar Resep

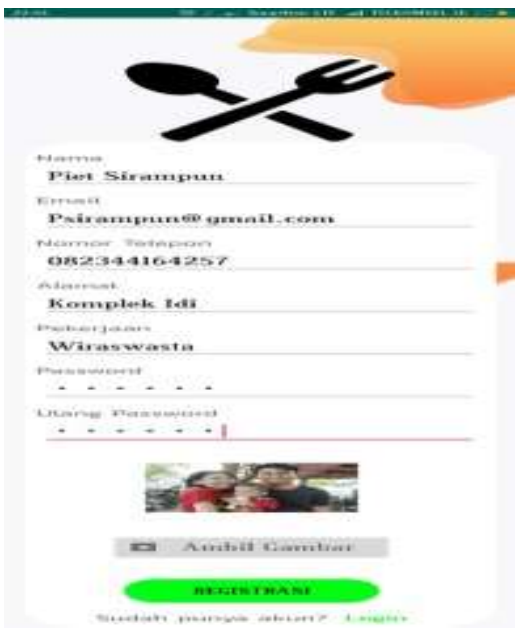

Gambar 11 . Tampilan untuk Registrasi Pengunjung

Pada gambar 11 terdapat daftar user menampilkan gambar tempat user melakukan pendaftaran.

3. Tampilan Beranda Utama Pengunjung

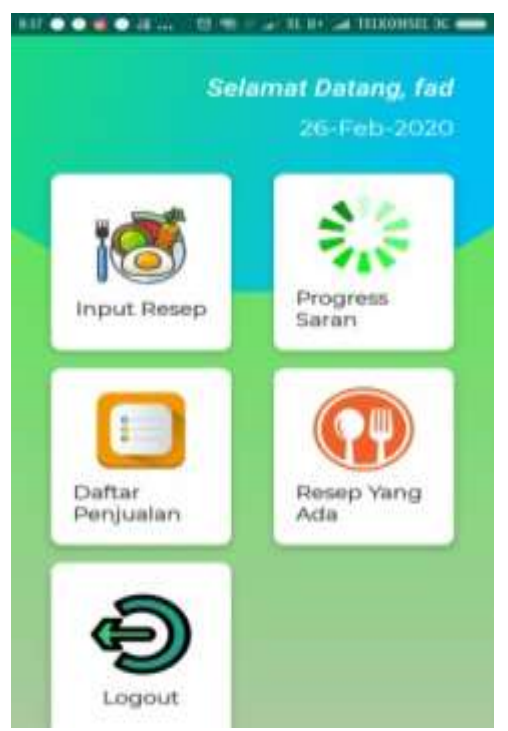

Gambar 12. beranda utama Pengunjung

Pada gambar 12 terdapat beranda utama pengunjung menampilkan gambar tempat pengunjung dapat melakukan proses input resep, melihat progress, daftar penjualan dan resep yang ada.
4. Tampilan Jendela Progress Saran

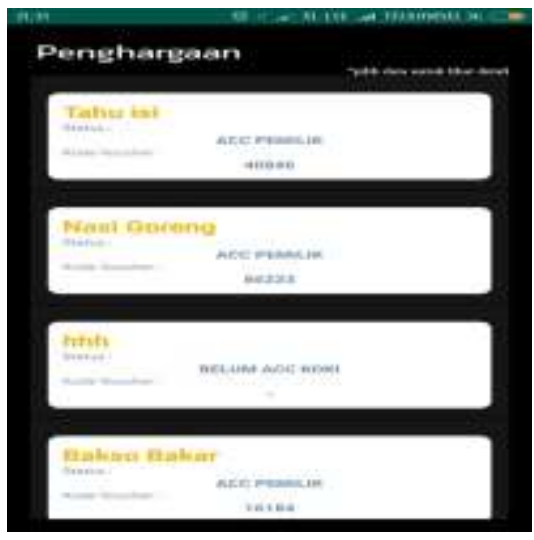

Gambar 13 Tampilan jendela progress saran pada gambar 13 terdapat jendela progress saran menampilkan gambar yang merupakan tempat user melihat penghargaan yang didapat.

5. Tampilan Jendela Klain voucher

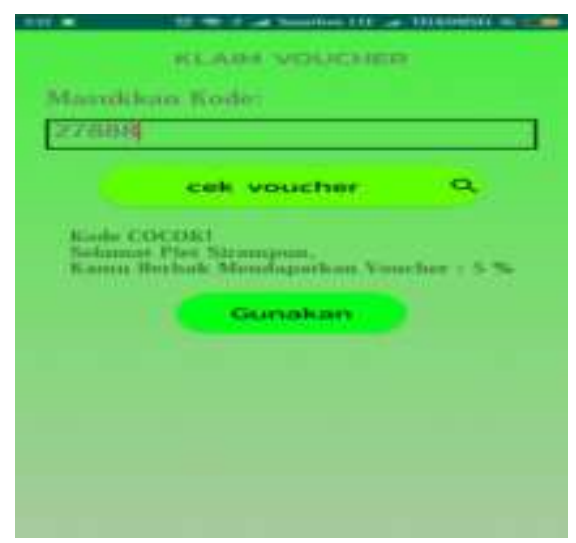

Gambar 14. Tampilan Jendel Klaim Voucher

Pada gambar 14. Terdapat tampilan untuk pengunjung bisa klaim voucher menampilkan gambar tempat kasir menukarkan voucher pengunjung.

6. Tampilan Jendela penentuan harga resep

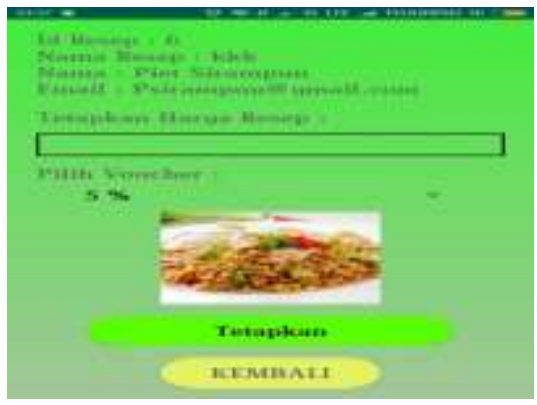

Gambar 15. Tampilan Jendel Klaim Voucher 
Pada gambar 15 terdapat penerapan harga menampilkan gambar tempat pemilik menentukan harga dan voucher.

\section{B. Pengujian}

Pengujian Sistem yang dilakukan dengan menggunakan metode pengujian langsung berdasarkan teknik Black Box dengan menguji fungsionalitas dari sistem, tombol dan kesesuaian hasil sistem yang telah dirancang.

Tabel 1 . Pengujian sistem

\begin{tabular}{|c|c|c|c|c|}
\hline No & $\begin{array}{r}\text { Skenario } \\
\text { Pengujian }\end{array}$ & Hasil Yang Diharapkan & $\begin{array}{c}\text { Hasil } \\
\text { Pengujian }\end{array}$ & Kesimpulan \\
\hline 1. & $\begin{array}{l}\text { Menjalankan } \\
\text { program }\end{array}$ & $\begin{array}{l}\text { Berhasil menampilkan } \\
\text { form login }\end{array}$ & $\begin{array}{l}\text { Sesuai } \\
\text { harapan }\end{array}$ & Valid \\
\hline 2. & Klik button login & $\begin{array}{l}\text { Berhasil masuk } \\
\text { dashboard }\end{array}$ & $\begin{array}{c}\text { Sesuai } \\
\text { harapan }\end{array}$ & Valid \\
\hline 3. & $\begin{array}{l}\text { Klik tombol Ambil } \\
\text { Gambar }\end{array}$ & $\begin{array}{l}\text { Berhasil menambahkan gambar pada form } \\
\text { daftar user }\end{array}$ & $\begin{array}{l}\text { Sesuai } \\
\text { harapan }\end{array}$ & Valid \\
\hline 4. & $\begin{array}{l}\text { Klik } \quad \text { tombol } \\
\text { Registrasi }\end{array}$ & $\begin{array}{l}\text { Berhasil menyimpan data- data pengunjung } \\
\text { yang ingin mendaftarkan dirinya menjadi } \\
\text { user }\end{array}$ & $\begin{array}{l}\text { Sesuai } \\
\text { harapan }\end{array}$ & Valid \\
\hline 5. & Klik Login & Berhasil kembali $\quad$ ke halaman login & $\begin{array}{c}\text { Sesuai } \\
\text { harapan }\end{array}$ & Valid \\
\hline 6. & $\begin{array}{l}\text { Klik tombol input } \\
\text { resep }\end{array}$ & Berhasil masuk pada form input resep & $\begin{array}{l}\text { Sesuai } \\
\text { harapan }\end{array}$ & Valid \\
\hline 7. & $\begin{array}{l}\text { Klik tombol Ambil } \\
\text { Gambar }\end{array}$ & $\begin{array}{l}\text { Berhasil menambahkan gambar pada form input } \\
\text { resep }\end{array}$ & $\begin{array}{c}\text { Sesuai } \\
\text { harapan }\end{array}$ & Valid \\
\hline 8. & $\begin{array}{l}\text { Klik Tombol Kirim } \\
\text { Resep }\end{array}$ & $\begin{array}{l}\text { Berhasil menyimpan data resep yang diajukan } \\
\text { oleh pengunjung }\end{array}$ & $\begin{array}{c}\text { Sesuai } \\
\text { harapan }\end{array}$ & Valid \\
\hline 9. & $\begin{array}{ll}\text { Klik } & \text { Tombol } \\
\text { Kembali } & \end{array}$ & Berhasil kembali ke menu utama & $\begin{array}{l}\text { Sesuai } \\
\text { harapan }\end{array}$ & Valid \\
\hline 10. & Klik Progress Saran & menampilkan penghargaan & $\begin{array}{l}\text { Sesuai } \\
\text { harapan }\end{array}$ & Valid \\
\hline 11. & $\begin{array}{l}\text { Klik tombol daftar } \\
\text { penjualan resep }\end{array}$ & $\begin{array}{l}\text { Berhasil masuk form daftar penjualan } \\
\text { resep }\end{array}$ & $\begin{array}{l}\text { Sesuai } \\
\text { harapan }\end{array}$ & Valid \\
\hline 12. & $\begin{array}{l}\text { Klik data daftar } \\
\text { penjualan resep }\end{array}$ & $\begin{array}{l}\text { Berhasil menampilkan detail daftar penjualan } \\
\text { resep }\end{array}$ & $\begin{array}{c}\text { Sesuai } \\
\text { harapan }\end{array}$ & Valid \\
\hline 13. & $\begin{array}{l}\text { Klik tombol resep yang } \\
\text { ada }\end{array}$ & menampilkan daftar resep yang & $\begin{array}{c}\text { Sesuai } \\
\text { harapan }\end{array}$ & Valid \\
\hline 14. & $\begin{array}{l}\text { Klik data daftar } \\
\text { resep }\end{array}$ & menampilkan detail daftar resep & $\begin{array}{l}\text { Sesuai } \\
\text { harapan }\end{array}$ & Valid \\
\hline 15 . & Klik Logout & Berhasil keluar dari menu pengunjung & $\begin{array}{c}\text { Sesuai } \\
\text { harapan }\end{array}$ & Valid \\
\hline
\end{tabular}

Setelah dilakukan pengujian dengan motode black box bahwa pegujian telah berhasil dan terbebas dari yang dapat dilihat berdasarkan Tabel 5.29, dinyatakan 


\section{KESIMPULAN}

Dari hasil implementasi aplikasi berbasis android untuk pengembangan ide masakan dan minuman pada restoran serta pengujian yang dilakukan penggunaan aplikasi ini pemilik restoran dapat mengembangkan resep masakan dimana menerima ide resep masakan dari pengunjung dan dapat dengan mudah melihat penjualan yang terjadi di restoran serta dapat membantu koki dalam mengimplemetasi resep yang telah diberikan oleh pengunjung sehingga menambah jumlah menu makanan yang ada direstoran. Dari 25 pengunjung yang dating 20 pengunjung diantaranya memberikan rekomendasi resep makanan yang di perlukan. Dimana hanya 10 resep yang di setujui oleh owner restoran yang dimana akan dilihat hasil penjualannya.

\section{DAFTAR PUSTAKA}

[1] A. H. Sancoko, "Strategi Pengembangan Bisnis Usaha Makanan Dan Minuman Pada Depot Time To Eat Surabaya," AGORA, vol. 3, no. 1, pp. 185-194, 2015.

[2] M. Qadhafi, A. Sukmaaji, and R. Purnama, "Rancang Bangun Aplikasi Pemesanan Makanan Online Pada Restoran Cepat Saji Berbasis Mobile Application (Studi Kasus Chiken Mania Cabang Rungkut)," J. JSIKA, vol. 1, no. 2, pp. 1-11, 2012.

[3] S. M. Jaya, "Aplikasi Pemesanan Makanan Berbasis Android Di Restoran 4 Sekawan," INTI TALAFA J. Tek. Inform., vol. 9, no. 2, pp. 13-24, 2017.

[4] R. Suarantalla, F. A. Nugroho, and K. Hermanto, "Rancang Bangun Aplikasi Pemesanan Makanan Berbasis Android Pada Rumah Makan 'Begawan Tepi Sawah,"' Hexag. J. Tek. dan Sains, vol. 1, no. 2, pp. 42 $51,2020$.

[5] J. F. Tompoh, S. R. Sentinuwo, and A. A. E. Sinsuw, "Rancang Bangun Aplikasi Pemesanan Menu Makanan Restoran Berbasis Android," E-Journal Tek. Inform., vol. 9, no. 1, pp. 1-9, 2016.

[6] G. Mary B and K. G. R, "Research Contribution. Who Will Direct Hospital Food service Departments in the Future?," $J$. Foodserv. Manag. Educ., vol. 4, no. 1, pp. 14, 2010.

[7] K. Muludi, D. Kurniawan, and L. A. Rani, "Penerapan Metode Case Based Reasoning Pada Pengembangan Aplikasi Recipe Recommendation Berbasis Android," $J$. Komputasi, vol. 4, no. 2, pp. 12-22, 2016.

[8] Mashud and Herni, "Aplikasi Analisis Laporan Keuangan Dengan Metode Analisis Rasio Keuangan Berbasis Web Pada PT. Sinar Galesong Mandiri," J. Inspir., vol. 8, no. 2, pp. 103-111, 2018.
[9] Y. Supardi, Sistem Opersi Andal Android. Jakarta: Elex Media Komputindo, 2012.

[10] F. P. Sari, "Aplikasi Sistem Informasi Pemessanan Koki dan Masakan Rumahan Berbasis Android," SINTECH J. Sist. Inf. dan Tenologi, vol. 1, no. 2, pp. 123-126, 2018.

[11] Sukamto, A. Rosa, and M. Shalahuddin, Rekayasa Perangkat Lunak (Terstruktur dan Berorientasi Objek). Bandung: Informatika, 2014. 